\author{
Piotr SobotKa
}

\title{
Wilhelm von Humboldt a Jan Baudouin de Courtenay i Ferdinand de Saussure: filozoficzne podstawy nowożytnej myśli lingwistycznej*
}

Słowa klucze: epistemologia; jednostka lingwistyczna; znak; poznanie; poglądy na naturę języka

Ke y w ords: epistemology; linguistic unit; sign; cognition; views on the nature of language

W artykule poświęconym Janowi Baudouinowi de Courtenay zasugerowałem, po przywołaniu zbliżonych koncepcyjnie i paralelnych wypowiedzi Ferdinanda de Saussure'a (2002: 165-166; 2004: 160-161) i Baudouina (1922: 12), że obaj badacze mogli odwoływać się do poglądów Wilhelma von

* Rozbudowany i poprawiony tekst referatu wygłoszonego podczas 77 Zjazdu Polskiego Towarzystwa Językoznawczego w Częstochowie (16-17 września 2019 r.). Fragmenty wystąpienia odnoszące się do Jana Baudouina de Courtenay wpisują się w prace realizowane w ramach programu Ministra Nauki i Szkolnictwa Wyższego pod nazwą „Narodowy Program Rozwoju Humanistyki” w latach 2018-2023, nr projektu 11H 17 006685 . 
Humboldta, co tłumaczyłoby zbieżność wyrażonych przez nich sądów ${ }^{1}$ (por. Sobotka 2017). Celem mojej obecnej wypowiedzi jest próba syntetycznego i konfrontacyjnego nakreślenia poglądów odnoszących się do teorii języka Humboldta, Baudouina i Saussure'a, wskazanie zależności między tymi koncepcjami, prześledzenie najważniejszych z perspektywy rozwoju teorii języka związków między myślicielami oraz sformułowanie hipotezy objaśniającej filiacje między ich doktrynami. Możliwe są trzy warianty. Po pierwsze, wspólne dla Baudouina i Saussure'a sądy są wynikiem wzajemnych kontaktów między lingwistami i wymiany myśl. Po drugie, obaj, niezależnie od siebie, doszli do podobnych wniosków². Po trzecie, niektóre zbliżone do siebie wypowiedzi Baudouina i Saussure’a można traktować jako efekt oddziaływania myśli innych uczonych, m.in. Wilhelma von Humboldta, bądź wpływu ogólnie panujących w lingwistyce przełomu XIX i XX wieku tren-

1 Pomysł tego pokrewieństwa skonsultowałem z dr Elżbietą M. Kowalską, tłumaczką pism lingwistycznych Humboldta na język polski, która w jednym z listów do mnie napisała m.in.: „O ile mi wiadomo, humboldtyści poprzestają li tylko na spekulacjach, w jakim stopniu Saussure ewentualnie mógł był czerpać z Humboldta. Nie wyklucza się pewnych afiliacji, ale dowodów nie ma. Natomiast zbieżności są oczywiste”. I dalej: „O ile mi wiadomo, Saussure nie czytał Humboldta, ale może idee fruwały w powietrzu naukowym. Jeżeli przyjął się język, zaakceptowano i myśli, a Saussure je rozwinął”. A w zakończeniu listu: „Przesłane cytaty nie dosłownie, lecz jednak są mocno zbieżne z Humboldtem, zwłaszcza Saussure, Baudouin mniej”. W innym z kolei liście dr Kowalska napisała: „[...] nie zdarzyło mi się dotąd czytać tekstów Baudouina, a tylko jakieś ogólnikowe omówienia jego teorii. Po lekturze przesłanych teraz przez Pana cytatów jestem wręcz wstrząśnięta ich zbieżnością, również terminologiczną, z tekstami i myślą Humboldta".

${ }^{2}$ Historia językoznawstwa zna kilka takich przypadków, np. prawo Raska-Grimma czy prawo/prawa Fortunatowa-de Saussura. W tym ostatnim wypadku obaj uczeni niezależnie od siebie odkryli kolejne regularności zmian głosowych: 1) w zakresie konsonantyzmu staroindyjskiego (prawo zwykle przypisywane Saussure'owi, lecz jako pierwszy ogłosił je Filipp F. Fortunatow) i 2) przesunięcia akcentu indoeuropejskiego w językach bałtosłowiańskich (prawo zazwyczaj określane jako prawo Fortunatowa-de Saussure'a, choć obie koncepcje różnią się od siebie zasięgiem zachodzenia prawa), por. Collinge (1985: 41-46, 149-152, 232-233). Saussure w latach gimnazjalnych odkrył, że greckie $\alpha$ poprzedzające końcówkę 3. os. pluralis perfecti passivi jest kontynuantem praindoeuropejskiego sonantu nosowego $m$, spostrzeżenie to - w wersji rozszerzonej - zostało następnie ogłoszone przez Karla Brugmanna (por. Danielewiczowa 2016: 50). Saussure zresztą powrócił do problemu indoeuropejskiego *a w swoim lipskim licencjacie (Saussure 1879). Niezależne odkrycia równoległe nie są jednak zupełnie przypadkowe. Wymagają spełnienia określonych warunków: paralelnych danych, zbliżonej metody ich interpretacji itd. [Za tę ostatnią uwagę dziękuję mgr. Kacprowi Kardasowi]. 
dów. W wypadku Saussure'a - jeśli ten, jak przypuszczam, nie czytał pism Humboldta - wątki humboldtiańskie w jego doktrynie mogły pojawić się pod wpływem innych badaczy, przede wszystkim Williama Dwighta Whitneya, lecz również kazańczyków, o których Saussure pisał w kontekście niezbyt pochlebnej i jedynej zachowanej w dostępnych nam źródłach wypowiedzi na temat Humboldta:

Gdybym wziął pod rozwagę te prace, od Wilhelma Humboldta aż do Hermana Paula i psychologa Wundta, to musiałbym stwierdzić, że wszystkie one są wypełnione materiałem, który mógłby posłużyć do wzniesienia budowli [teorii języka - PS], ale że żadna z nich nie zaznaczyła nawet fundamentu owej budowli. Kilku językoznawców rosyjskich, a mianowicie Baudouin de Courtenay i Kruszewski, było bliżej niż ktokolwiek inny teoretycznego spojrzenia na język, nie wychodząc przy tym poza rozważania czysto językoznawcze; są oni zresztą nieznani ogółowi uczonych zachodnich (Saussure 2004: 239).

Zdaniem Magdaleny Danielewiczowej (2004: 14; 2016: 78-79, 265-266) oraz Andrzeja Bogusławskiego i Ewy Drzazgowskiej (2016: 232-234) Saussure nie tylko znał pisma Humboldta, ale i często je cytował. Danielewiczowa (2004: 14) w przedmowie do przekładu Écrits... pisze, że Saussure niejednokrotnie przywołuje w swych pismach Humboldta, natomiast w monografii poświęconej Saussure'owi sugeruje możliwą zależność między doktryną Humboldta a teorią Saussure'a oraz znajomość przez tego ostatniego wstępu - jeśli dobrze odtwarzam tok wykładu M. Danielewiczowej - do rozprawy Humboldta o języku kawi (Über die Verschiedenheit des menschlichen Sprachbaues un ihren Einfluß auf die geistige Entwicklung des Menschengeschlechts). Dodaje przy tym, że istotne uwagi na ten temat można znaleźć w opracowaniu A. Bogusławskiego i E. Drzazgowskiej, którzy expressis verbis piszą:

Pewne najbardziej ogólne rysy ujęcia de Saussure’a, zwłaszcza kluczowe rysy „ekspresyjno-logocentryczne”, wywodzą się, przy wszystkich znamiennych różnicach między myślicielami, nade wszystko z puścizny Humboldta [...]. Paralelna lektura dzieł obu myślicieli przekonuje o obecności w pismach de Saussure'a licznych filiacji, nawet sformułowaniowych, w stosunku do ujęć Humboldta (w dalszej perspektywie można mówić także o kantiańskiej ramie światopoglądowej, która była mocno obecna w wizji Humboldta) (Bogusławski i Drzazgowska 2016: 232-233). 
Autorzy jednak nie przytaczają konkretnych wypowiedzi Saussure'a zaczerpniętych jakoby z prac Humboldta.

Zgodnie z przekazem Sechehayego (1917), Saussure przekraczał tradycyjne ujęcia filozoficzne, do których Sechehaye zalicza m.in. doktrynę W. von Humboldta. Według Sljusarevej (1974: 268), powołującej się w tym miejscu na Sechehayego (1917) i Šor (por. Соссюр 1933), jest bardzo prawdopodobne, że Saussure nie przeczytał ani Einleitung in das gesamte Sprachstudium (Humboldt 1908: 619-628) [Wprowadzenie w kompleksowe studium jęzkkoznawstwa], ani Über das vergleichende Sprachstudium in Beziehung auf die verschiedenen Epochen der Sprachentwicklung (Humboldt 1905: 1-34) [O językoznawstwie porównawczym w odniesieniu do różnych epok rozwoju języka]. Zdaniem badaczki, która najwyraźniej nie znała jeszcze opublikowanej przez Englera, a przytoczonej wyżej (por. s. 29) notatki, pominięcie Humboldta przez Saussure'a mogło mieć związek z wpływem niektórych koncepcji tego pierwszego (atomizm, historycyzm) na młodogramatyków, w stosunku do których Saussure pozostawał krytyczny, a zwłaszcza wobec ich rozumienia teorii języka. Według niej źródłem poznania idei Humboldta były dla Saussure’a prace W. D. Whitneya. Poza przenikaniem myśli Humboldta do saussuriańskiej koncepcji języka za pośrednictwem Whitneya, należy wziąć również pod uwagę krążące w dyskursie naukowym przekazy innych uczonych, relacjonujące mniej lub bardziej wiernie doktrynę Humboldta, która na przełomie XIX i XX wieku zdążyła już się pokryć patyną czasu.

Podstawę eksploracji i źródło formułowanych wniosków mojego wystąpienia stanowią rozprawy naukowe Humboldta, Baudouina i Saussure'a (por. Humboldt 1903-1936; Бодуэн де Куртенэ 1963a, 1963b; Baudouin de Courtenay 1975-1990; Saussure 1995, 2002; Baudouin de Courtenay 2016b) oraz ich listy (Benveniste 1964; Sljusareva 1970; Baudouin de Courtenay 2002; Humboldt 2004-2018; Baudouin de Courtenay 2007, 2011; Saussure 2014), odwołuję się również do literatury filozoficznej oraz opracowań z zakresu historii językoznawstwa. Mimo takiej rozległości obserwacji, temat, którego się podjąłem, z gruntu skazany jest na spekulacje, a być może i niepowodzenie ${ }^{3}$.

3 Dodatkową trudność sprawiają zmiany głoszonych przez omawianych badaczy tez. Nie ma jednej i jednolitej ich doktryny, lecz kilka, czasem niezależnych od siebie, a nawet sprzecznych ze sobą ujęć. Problem dotyczy zwłaszcza Baudouina, który kilkakrotnie 
Wilhelm von Humboldt - co zrozumiałe - nie tylko nie cytował Saussure'a i Baudouina, ale i nie korzystał z ich dorobku, nawet w sposób niejawny - Baudouin de Courtenay urodził się 10 lat po śmierci Humboldta, a de Saussure - 22 lata po śmierci Niemca. Baudouin kilkakrotnie przywoływał w swoich pismach Humboldta, uznając go za prekursora „,nowszego językoznawstwa «fillozoficznego», czyli ogólnego" (Baudouin de Courtenay 1903b: 284), nawiązywał do niego również niebezpośrednio, o czym sam wspomina w jednej z wypowiedzi:

Mimo że Steinthal bezpośrednio o „,analogii” mówi bardzo niewiele, to jednak naprowadza na nią, ponieważ nieustannie podkreśla psychiczną naturę języka i nieodzowność psychologicznego wyjaśniania jego zjawisk. Ponieważ zaś poglądy Steinthala rozwinęły się głównie pod wpływem nieśmiertelnych dzieł Wilhelma von Humboldta, jasne jest, że ostatecznie powstanie w mojej głowie myśli objaśniania zmian językowych za pomocą ,analogii” zawdzięczam po części W. von Humboldtowi (Baudouin de Courtenay 2016a: 34).

Na Saussure’a zaś powoływał się głównie w kontekście poczynionych przez niego odkryć z zakresu gramatyki porównawczej, a zwłaszcza fonetyki i fonologii. Wysoko oceniał rozprawę Saussure'a poświęconą wokalizmowi indoeuropejskiemu, szczególnie wiązanie przez Szwajcara „stosunków fonetycznych z budową morfologiczną wyrazów" (Baudouin de Courtenay 1909: 220). Wiemy ponadto z przekazów jego uczniów, że pojęcie fonemu pośrednio zapożyczył poprzez Kruszewskiego właśnie od de Saussure’a (por. Nitsch 2011: 289), a także że podzielał z nim poglądy na złożoną naturę rzeczywistości znakowej (por. Baudouin de Courtenay 1904: 126), choć w tym wypadku - jak zobaczymy niżej - trudno rozgraniczyć wpływ Humboldta od wpływu Saussure’a, którego - jak twierdzi E. Stankiewicz (1986: 6-7) Baudouin uważał za ,,prawdziwego innowatora teorii lingwistycznej”. Natomiast Saussure przywołał Humboldta bezpośrednio tylko raz w uwagach dotyczących Programu i metod językoznawstwa teoretycznego Alberta Sechehaye'go (por. wyżej), a Baudouina raz w napisanym po łacinie liście do

zmieniał swoje poglądy, nie rozwijał niektórych myśli. W artykule skoncentruję się głównie na stałych czy względnie stałych elementach teorii Humboldta, Baudouina, Saussure'a. 
Kazimierasa Jauniusa, w którym określa Baudouina swoim przyjacielem (nobis amicus) ${ }^{4}$, i dwukrotnie w Szkicach..., por. wyżej oraz:

[...] studia nad istniejącymi językami okazałyby się prawie całkowicie bezowocne, a w każdym razie pozbawione zarazem metody i jakiejkolwiek rządzącej nimi zasady, gdyby nie dążyły nieustannie do wyświetlenia ogólnego problemu języka, gdyby nie chciały poszukiwać w każdym szczegółowym zjawisku, które się zaobserwuje, sensu i wyraźnej korzyści, jakie z niego wynikają dla naszej wiedzy o możliwych operacjach ludzkiego instynktu odnoszącego się do mowy. I nie ma w tym nic nieokreślonego ani też ogólnikowego; każda osoba choćby trochę biegła w naszych badaniach wie, jaką radość przeżywa i jaki triumf święci badacz, kiedy napotyka nowe, teoretyczne zjawisko, nieważne, gdzie: w ostatnim z naszych dialektów czy w najdrobniejszym polinezyjskim narzeczu. Jest to kamień, który dokłada on do wznoszonej budowli i dzięki temu sprawia, że się ona nie zawali. Obecnie w każdej gałęzi wiedzy o językach wszyscy nieustannie zabiegają o to, by wyświetlić te zjawiska, które mogą być interesujące dla mowy ludzkiej w ogólności. I rzecz znamienna, teoretyczne obserwacje, jakich dostarczają ci, którzy są skoncentrowani na badaniu tej czy innej dyscypliny szczegółowej, jak np. germańszczyzny czy romańszczyzny, są o wiele bardziej cenione i uznawane niż obserwacje językoznawców obejmujących jakąś większą liczbę języków. Zdajemy sobie sprawę, że to właśnie najmniejszy szczegół tych zjawisk stanowi równocześnie ich ostateczną rację bytu i że zatem jedynie największa specjalizacja może efektywnie służyć największej generalizacji. To nie tacy językoznawcy, jak Friedrich Müller z Uniwersytetu Wiedeńskiego, którzy chcą ogarnąć prawie wszystkie narzecza kuli ziemskiej, dokonali kiedykolwiek poważnego kroku w dziedzinie poznania mowy ludzkiej; nazwiska, które należałoby tutaj przywołać, to raczej nazwiska romanistów, takich jak panowie Gaston Paris, Paul Meyer, jak pan Schuchardt, nazwiska germanistów, jak pan Hermann Paul, nazwiska ze szkoły rosyjskiej, zajmującej się w sposób szczególny językiem rosyjskim i językami słowiańskimi, jak panowie N. Baudouin de Courtenay czy M. Kruszewski (Saussure 2004: 145-146)5.

${ }^{4}$ List został napisany po łacinie. Saussure nie potrafił napisać go po rosyjsku, polsku czy litewsku, a nie był pewien, czy Jaunius zna francuski lub niemiecki. List nie doczekał się odpowiedzi, badacz przypuszczał nawet, że Jaunius - ze względu na język - mógł uznać go za kiepski żart (une mauvais plauisanterie).

${ }^{5}$ U Humboldta odnajdujemy analogiczną myśl. Według niego badanie języków etnicznych ma prowadzić do sformułowań ogólnych, które winny stanowić istotę badań językoznawczych. 
Ponadto znamy dwa listy Saussure'a do Baudouina z 1889 r., okresu, kiedy to Genewczyk żywo się interesował zagadnieniem akcentu litewskiego ${ }^{6}$ (por. Sljusareva 1970; Saussure 2014: 144-145, 149-151). Potwierdzają one, że obaj lingwiści się poznali, do ich pierwszego spotkania doszło w grudniu 1881 roku Baudouin został przedstawiony w Société de linguistique de Paris 19 listopada 1881, ale Saussure nie uczestniczył w tym spotkaniu, był on obecny dopiero 3 grudnia, w dniu wyboru Baudouina na członka Towarzystwa, oraz na kolejnych posiedzeniach - 17 grudnia i 7 stycznia 1882 r. W tym czasie, do listopada 1882 r., Baudouin prezentował na spotkaniach Towarzystwa prace swoje i Mikołaja Kruszewskiego. Saussure jako asystent sekretarza SLP otrzymał pisemną wersję odczytów Baudouina oraz inne jego teksty (por. Sljusareva 1970: 11-12).

Relacje między uczonymi, choć oficjalne, oparte były na pewnym rodzaju konwencjonalnego szacunku młodego de Saussure'a w stosunku do starszego kolegi. Nazwał go kurtuazyjnie w liście pisanym z Genewy „wybitnym uczonym, o którym nie zapomniano w Paryżu" (Saussure 2014: 150), choć w innym miejscu pisał o nim jako o nieznanym lingwiście, i prosił na zakończenie tego listu o przyjęcie wyrazów jego poważania o szczególnym znaczeniu, zaś pierwszy list zakończył zapewnieniami poważania i niezwykłego uznania. W archiwum de Saussure’a nie odnaleziono listów od Baudouina (Бодуэн де Куртенэ 1963b: 389).

Kilkakrotnie zwracano już uwagę w literaturze poświęconej historii myśli lingwistycznej na paralele między teoriami Humboldta i Baudouina (por. np. Adamska-Sałaciak 1996; Kowalski 2016; Hurch 2018), Humboldta i Saussure'a (Buyssens 1954; Waterman 1970; Sljusareva 1974; Bogusławski i Drzazgowska 2016) oraz Baudouina i Saussure'a (Щерба 1929; Meillet 1937; Слюсарева 1970; Koerner 1973; Feudel 1976; Stankiewicz 1986; Minissi 1989; H. Tóth 1997; Kowalski 2016). Tinatin Šeradzenidze, Arleta Adamska-Sałaciak i inni historycy lingwistyki wskazują, że definicja języka skonstruowana przez Baudouina odwołuje się zarówno pod względem

${ }^{6}$ W 1889 r. de Saussure przedstawił na spotkaniu Société de linguistique de Paris referat na temat akcentu litewskiego. To wystąpienie stało się podstawą opublikowanego w 1894 r. w rozprawach Towarzystwa artykułu pt. À propos de l'accentuation lituanienne (Saussure 1894a). Kolejne publikacje związane z tym zagadnieniem ukazały się w 1894 i 1896 (Saussure 1894b, 1896). Ten ostatni artykuł został oparty na wystąpieniu z 1894 (por. Petit i Quijano 2008). 
terminologicznym (ergon-cum-energeia), jak i koncepcyjnym do ustaleń Humboldta (Шарадзенидзе 1980: 34-36; Adamska-Sałaciak 1998: 32). Eric Buyssens uważa Saussure'a za ucznia (disciple) Humboldta (Buyssens 1954: 140), a John T. Waterman (1970) podkreśla humboldtiańskie inspiracje w teorii de Saussure (por. Mueller 1966: 97). Antoine Meillet (1937: 478) pisze, że między Saussure'a a Baudouinem nie ma zasadniczych różnic metodologicznych. Z kolei Lew Ščerba (Щерба 1929) dostrzega ogromne zbieżności nauki de Saussure'a z tezami Baudouina w zakresie teorii znaku, rozróżnienia systemu i jego użycia, podkreślenia znaczenia językoznawstwa synchronicznego ${ }^{7}$ :

Kiedy w 1923 r. otrzymaliśmy w Leningradzie Cours de linguistique générale de Saussure’a (wydanie pośmiertne wykładów z językoznawstwa ogólnego znakomitego lingwisty, profesora Uniwersytetu Genewskiego - książkę doskonałą i wywołującą wrażenie przede wszystkim na Zachodzie), byliśmy zaskoczeni licznymi zbieżnościami nauki de Saussure'a z oczywistymi dla nas tezami. Rozróżnienie języka jako systemu i języka jako realizacji (langue i parole u de Saussure'a), nie tak ścisłe i nie tak rozwinięte jak u de Saussure’a, właściwe było dla Baudouina. Poza tym cała nauka Baudouina o „fonemie” jako czymś stałym, niezmiennym, mającym lub mogącym mieć asocjacje semantyczne i dlatego mającym znaczenie społeczne, w odróżnieniu od dźwięku urzeczywistniającego się tylko w mowie, opiera się w istocie na tym rozróżnieniu. Tak charakterystyczne dla de Saussure'a podkreślanie wagi ,językoznawstwa synchronicznego", jak już to widzieliśmy wyżej, jest jedną z podstaw całej działalności

7 Baudouin uważał m.in., że ,Jest rzeczą w najwyższym stopniu niewłaściwą mierzyć budowę języka w pewnym czasie kategoriami jakiegoś wcześniejszego lub późniejszego momentu. Zadanie [...] polega na tym, by w drodze szczegółowej analizy języka w poszczególnych okresach ustalić jego kolejne im odpowiadające stany [...]” (Бодуэн де Куртенэ 1871). Saussurowskiemu przeciwstawieniu synchronii i diachronii w języku odpowiadają u Baudouina terminy statyka, dynamika. Do zmian językowych dochodzi w pewnym układzie społecznym. Według Baudouina jedną z możliwości zrozumienia istoty dynamicznej zmiany językowej jest jej badanie w procesach zachodzących w statycznych jednorodnych układach społecznych języka. Baudouin nie utożsamia diachronii (rozumianej jak u Saussure'a jako serii następujących po sobie stanów języka) z dynamiką, a synchronii (rozumianej w kategoriach współistnienia elementów językowych) ze statyką (por. Sobotka 2017: 20). Diachronia jest konceptualizowana nie tylko jako strumień (aspekt dynamiczny diachronii), lecz także jako kontynuacja tego, co jest historycznie trwałe i stabilne (aspekt statyczny diachronii); natomiast synchronia to nie tylko niezmienność (aspekt statyczny synchronii), ale również regularna wariantywność i trwająca w czasie zmiana (aspekt dynamiczny synchronii) (por. Lenček 1989: 75). 
naukowej Baudouina. Znakowy charakter języka, na który zwraca uwagę de Saussure, można paralelnie zestawić z pojęciem „semazjologizacji lub morfologizacji”, tj. podstawowym dla systemu poglądów Baudouina pojęciem, zgodnie z którym tylko to, co jest „semazjologiczne lub zmorfologizowane”, tj. to, co okazuje się „znakiem”, co ma jakąkolwiek funkcję, może być uważane za fakt lingwistyczny, czy to szyk, intonacja, grupa dźwięków lub pojedynczy dźwięk, czy nawet właściwość dźwięku, np. „miękkość”, a w dziedzinie języka wzrokowego także takie rzeczy, jak akapit, wielka litera itp. $Z$ drobniejszych zgodności można wskazać przykładowo pogląd o zerze fonetycznym i morfologicznym, jako czymś zasadniczo wspólnym dla obu autorów, i na wiele innych (Щерба 1957: 94-95).

Z kolei reakcja Evgenija Polivanova na Kurs... jest jeszcze ostrzejsza w wymowie niž Ščerby. Pisze bowiem:

[Kurs...] został przyjęty przez wielu jako jakieś objawienie, ale dosłownie nie zawiera on nic nowego w przedstawieniu i rozwiązaniu problemów ogólnojęzykowych w porównaniu z tym, co już dawno temu zostało osiągnięte u nas przez Baudouina i szkołę baudouinowską (Поливанов 1931: 3-4).

Mimo tak wielu świadectw wzajemnych filiacji między uczonymi, ich „potrójna”, porównawcza panorama nie została jednak do tej pory nawet naszkicowana, a mogłaby ona wprowadzić wiele nowych i zasadniczych wątków do wiedzy o języku, wyjaśniając niejako przy okazji to, co w koncepcjach Humboldta, Baudouina i Saussure'a wydaje się nam niespójne z ich ogólną wizją języka ${ }^{8}$.

Każda teoria języka zmierzająca do opisu relacji między językiem a rzeczywistością i światem, nawet jeśli nieświadomie, zakorzenia się w określonej koncepcji filozoficznej (por. Lyons 1977: 109). Porównywane ze sobą doktryny są silnie powiązane nie tylko z filozofią języka, lecz również z epistemologią i na ten właśnie ich aspekt kładę w wystąpieniu szczególny nacisk.

${ }^{8}$ Między uczonymi istnieje zaskakujące podobieństwo w zakresie stylistyki, kompozycji tekstów, jasności wykładu itp. Nie pozostawili oni po sobie ostatecznych redakcji swoich syntez, czym zazwyczaj się tłumaczy tak charakterystyczną dla nich niejasność wypowiedzi, brak konsekwencji, faktyczne sprzeczności. Te ostatnie pozwalają m.in. przedstawicielom diametralnie różnych nurtów językoznawczych odwoływać się do ustaleń tych uczonych, powoływać się na nich jako na prekursorów odmiennych, modnych współcześnie kierunków w lingwistyce. 
$\mathrm{Na}$ ogólnym, pojęciowym i teoriopoznawczym poziomie Humboldt jawi się jako idealista w wersji po części kantiańskiej, po części fichteańskiej i heglowskiej. Jego filozofia języka ma charakter generatywny. Chomsky (1970: 17) podkreślał, że pojęcie formy jako procesu generatywnego legło u podstaw ogólnego spojrzenia Humboldta na naturę języka, jego użycie i akwizycję. Humboldt traktował formę językową jako regułę proceduralną i kierunek badań zarazem, jako forma formans (Humboldt 1906: 455) 'formę formującą', a nie jako rodzaj materialnego kształtu, co współbrzmi z saussure'owskim ujęciem języka jako formy, a nie jako substancji (Saussure 1995: 157). Struktura i organizacja języka nie była zdaniem Humboldta zbiorem zaktualizowanych form słownych, stanowiących konstrukcję języka, jego gramatykę. Badanie języka na najbardziej podstawowym poziomie wiązało się z obserwacją procedur, jakimi posługuje się język w generowaniu mowy (Verfahrensweise der Sprache bei der Erzeugung der Rede), albowiem: ,język istnieje jedynie w dyskursie (verbundenen Rede), jego gramatyka i słownik są zaledwie porównywalne z jego martwym szkieletem (todten Gerippe)" (Humboldt 1907b: 147). Znak w rozumieniu Humboldta istnieje wyłącznie w sferze pojęciowej (mentalnej) i jest od niej zależny. Arbitralność i konwencjonalność języka nie wynikają ze społecznego uzgodnienia, lecz są efektem procesu generatywnego. „Istota myślenia polega na tym, że dokonujemy refleksji" (tu i poniżej: Humboldt 1908: 581). Humboldt utrzymuje, że odbywa się to poprzez akt, za pomocą którego podmiot myślący odróżnia się od samej myśli, tego, co zostało pomyślane (im Unterscheiden des Denkenden vom Gedachten), a umysł w jednym z kolejnych kroków może przystąpić do porównania kilku odrębnie pojmowanych jednostek (Einheit), obiektów pierwotnie odnoszonych do naszej działalności myślenia i odrębnych od nas, łącząc je na różne sposoby, by wreszcie wyciągać wnioski z takiego stanu rzeczy. Tym samym Humboldt kładzie podwaliny pod radykalnie nowe pojęcie znaku, które antycypuje zarówno ujęcie młodego Baudouina (Бодуэн де Куртенэ 1871), jak i definicję Saussure’a podaną w Cours de linguistique générale. $\mathrm{W}$ procesie segmentacji powstają nie tylko różne obiekty, ale wraz z nim sam podmiot tej działalności myślenia stanowi sam siebie. Żadne myślenie, nawet najczystsze (najbardziej abstrakcyjne?), nie może się obyć bez pomocy ogólnych form naszej zmysłowości (allgemeinen Formen unsrer Sinnlichkeit); dopiero za ich pośrednictwem może ono zostać uchwycone i niejako zatrzymane (auffassen und gleichsam festhalten). Wyraźnie pobrzmiewają 
w tych sformułowaniach wątki kantiańskie - akty mentalne nie obywają się bez oddziaływania ogólnych form naszej zmysłowości (por. Kant 2004). Język zaczyna się wraz z ,pierwszym aktem refleksji”, co Saussure ujął w kategoriach związanych z budowaniem opozycji. Zdaniem Šor system saussure’owskich opozycji językowych jest bardzo zbliżony do głównych założeń filozofii języka Humboldta (por. Соссюр 1933: 212). Trzeba jednak zaznaczyć, że w Über die Verschiedenheit des menschlichen Sprachbaues..., na którą to pracę powołuje się Šor, nie ma bezpośrednio mowy o antynomiach, różnicach, identyczności różnic czy oponujących ze sobą parach jednostek, choć w Über Denken und Sprechen pojawia się myśl o porównywaniu, łączeniu, dzieleniu jednostek przeciwstawianych (w refleksji na temat myślenia i języka) podmiotowi poznania jako jego obiekt epistemiczny (Humboldt 1908: 581). Natomiast w Über die Verschiedenheit... Humboldt wyraźnie przeciwstawia formę dźwiękową jej użyciu, polegającemu na oznaczaniu przedmiotów i łączeniu myśli (Humboldt 1907a: 52), czego odległym, rzecz jasna, refleksem może być podział zdolności mowy na jej aktualizację (langue) i indywidualną realizację (parole). Charakterystyka języka (rozumianego jako obiekt poznania) w kategoriach antynomii zakorzenia się oczywiście w antynomicznym ujęciu kantiańskiego „czystego rozumu” (por. Brown 1967; Kant 2013).

Proces segmentacji odbywa się zdaniem Humboldta na dwóch poziomach: mentalnego strumienia wrażeń i odpowiadającemu mu w dyskursie porządku zmysłowego. Współczesna lingwistyka strukturalna nazywa to „zasadą podwójnej artykulacji” (por. Martinet 1980: 13f). W procesie refleksji wyodrębniamy pewne segmenty z niekończącego się i amorficznego przepływu wrażeń i obrazów mentalnych, narzucając im jednocześnie porządek. To narzucenie porządku jest dziełem zmysłowego medium języka: dźwięki słów funkcjonują jako jednostki strukturalne (Einheiten), przez które rozpoznajemy i utrwalamy jednostki mentalne w przepływie wrażeń i obrazów. Mowa ludzka nie jest już zatem postrzegana przez Humboldta jako stosowanie i manipulowanie stałym systemem arbitralnych znaków, jak zakładali zarówno racjonaliści, jak i empirycy, ale polega raczej na operacji łączenia tych dwóch różnych zestawów porządków: artykulacyjnego dźwięku (u Saussure'a signifiant) i „myśli” (u Saussure'a signifié). Ponad sto lat później Saussure w Cours de linguistique générale zdefiniował język i znak językowy za pomocą prawie tych samych słów. Według Saussure’a na język składa się ,fakt, 
w pewnym stopniu tajemniczy, że «myśl-dźwięk» zakłada podziały oraz że język wypracowuje swe jednostki kształtując się między dwoma bezkształtnymi masami” (Saussure 1991: 121). „Dźwięk-myśl” implikuje zatem podziały czy opozycje proporcjonalne, które są ostatecznymi jednostkami językoznawczymi. Dźwięk i myśl mogą być łączone tylko za pomocą tych właśnie jednostek. W zbliżony sposób postrzegał rzeczywistość języka Baudouin de Courtenay, dla którego „[...] w języku łączą się w nierozerwalnym związku dwa elementy: fizyczny i psychiczny [...] kategorie fizjologiczne i psychologiczne przejawiają się w ściśle określonym obiekcie [...]” (Бодуэн де Куртенэ 1871: 61; 1963a). Forma dźwiękowa tego obiektu lingwistycznego wraz z jej funkcją (znaczeniem) tworzą zdaniem Baudouina tak ścisłą więź, że „,̇adna z tych dwóch części nie może podlegać zmianie, nie wywołując odpowiedniej zmiany w drugiej”. Idea ta obecna jest również u Saussure’a. W Kursie... czytamy, że jakakolwiek zmiana (zapewne chodzi o zmianę funkcjonalną) w jednym z aspektów znaku nieuchronnie prowadzi do przesunięcia związku między signifié a signifiant, do przesunięcia relacji między pojęciem a znakiem (por. Saussure 1995: 109). Źródeł tej myśli można szukać w pracy Schmidta (1865: 1) ${ }^{9}$, który z kolei być może pod wpływem czy za pośrednictwem Hugo Schuchardta (por. Hurch 2018: 628-629) przejął ją od Humboldta, dla którego język jest procesem dynamicznym, „wiecznie powtarzającym się działaniem umysłu zmierzającym do tego, aby artykułowany dźwięk był zdolny do wyrażania myśli" (Humboldt 1907a: 46). Działanie to nie wiąże się z żadnym ustalonym schematem, ponieważ artykułowany dźwięk nie jest raz na zawsze związany z myślą, lecz jest efektem działania artykulacyjnego (Artikulationstätigkeit), za pomocą którego dźwięk oddaje myśl (por. Ferron 2009: 103). Zmiany zatem formy skutkują przesuwaniem się relacji między formą a pojęciem, ustanawianiem jej na nowo, podobnie zmiany pojęciowe będą wymagały odnowienia więzi znaczenia z dźwiękiem. Z kolei u Baudouina forma dźwiękowa nie może się obyć bez funkcji słów, będących reprezentantami znaczących związków dźwiękowych. Funkcja zaś ,jest ściśle związana nie $\mathrm{z}$ brzmieniami i wyobrażeniami tych brzmień, ale $\mathrm{z}$ pewnymi poruszeniami organów i z wyobrażeniami tych poruszeń [...]” (Бодуэн де Куртенэ 1963a: 76), ma ona zatem charakter mentalny. Baudouina - jak

9 Por. „Forma i treść, dźwięk i myśl są tak nierozerwalnie związane ze sobą, że żadna z tych dwóch nie może być zmieniona bez zmiany drugiej”. 
widać - łączy z Humboldtem wizja języka jako zbioru abstrakcyjnie rozumianych wrażeń, składników, istniejących tylko in potentia, odróżnianych od ich realizacji, będących „nieprzerwanie powtarzającym się procesem” (Бодуэн де Куртенэ 1871: 77). To rozróżnienie w centrum swojej doktryny postawił potem de Saussure. Ujęcia znaku i języka zatem u Humboldta, Baudouina i Saussure'a krzyżują się, a na poziomie wyodrębniania obiektów lingwistycznego poznania pozostają niesprzeczne.

W świetle tego, co zostało powiedziane, to Humboldta trzeba uznać za pierwszego odkrywcę triadyczności mowy: Znaczenie (mówienie) definiowane jest przez niego jako synteza (zespolenie (accouplement) Saussure'a) dźwięku i idei - Ton oraz Vorstellung. Zgodność między podmiotem mówiącym a jednostką języka możliwa jest dzięki predeterminowaniu tej ostatniej przez podmiot. Refleksja empiryczna odkrywa prawidłowość odpowiadającą naszej formie umysłu (Humboldt 1907a: 61). Saussure'owska triada langagelangue-parole musi być porównywana $\mathrm{z}$ humboldtiańską koncepcją znaczenia, w którym odróżniane są dźwięk i myśl, a nie - jak sądził Hugo Mueller (1966: 99-102) - z podziałem dychotomicznym Ergon-Energeia. Podobną triadę odnajdziemy u Baudouina, dla którego na zjawiska mowne - pojmowane po humboldtiańsku jako uniwersalny refleks ducha na podrażnienia czyli podniety świata - składa się język oraz jego urzeczywistnienie, same zaś zjawiska mowne ujmowane są przez Baudouina jako niezbywalne zespolenie ich strony duchowej (mówienie) i zmysłowej (wymawianie). Pisał m.in.

[...] bez duszy może istnieć maszyna mówiąca, ale nigdy człowiek rozumiejący i uspołeczniony; a rozumienie i uspołecznienie są nieodzownym warunkiem prawdziwego języka (Baudouin de Courtenay 1904: 35-36).

Już w wykładzie inauguracyjnym z 1870 r. wygłoszonym na Uniwersytecie Petersburskim (por. Бодуэн де Куртенэ 1871)

zwracał uwagę na konieczność rozróżnienia dwu aspektów językowych wzajemnie się warunkujących. Pierwszy z nich rozumiany jako określony kompleks składników istniejący tylko in potentia nazwał po prostu językiem (jazyk), a drugi aspekt rozumiany jako «nieprzerwanie odnawiający się proces» otrzymał nazwę mowy (reč) (Heinz 1990: 24). 
Natomiast w zastosowaniu języka odpowiada im kolejna triada: wyobrażeń cerebracyjnych, rozumianych jako myślenie językowe indywidualne społecznie uruchomione, fonacyjnych i audycyjnych, tj. związanych ze skutkami akustycznymi ruchów fizjologicznych (Baudouin de Courtenay 1903a). Wszelkie zatem poznanie we wszystkich tych ujęciach zdeterminowane jest przez kognitywne struktury mentalne, jest odkrywaniem struktury własnego umysłu i zarazem struktury języka, stanowiącego przedmiot poznania „odrywany” niejako w procesie metarefleksji od podmiotu poznającego. Odtwarzanie obiektów lingwistycznych odbywa się - jak porządek poznania w koncepcji Kanta - w kierunku od podmiotu poznającego do obiektu poznawanego. Efektem zaś poznania jest realizacja języka.

Baudouina traktuje się w różnych opracowaniach m.in. jako prekursora strukturalizmu (por. Heinz 1978: 214-218). Jego poglądy rozwijały się dzięki nawiązaniu (czasem negatywnemu) do myśli Augusta Schleichera, Augusta Webera, Heymanna Steinthala, a przede wszystkim Wilhelma von Humboldta. Baudouin podkreśla zasadniczą różnicę między stroną fizyczną a językową dźwięków mowy, czego konsekwencją był postulat odróżnienia „fizjofonetyki” (antropofonetyki) i „fonetyki właściwej”, której podstawową jednostką jest fonem rozumiany jako abstrakcyjny inwariant, realizowany konkretnie w różnych postaciach alternacyjnych przede wszystkim na płaszczyźnie morfologicznej. Fonem zaś ma zdaniem Baudouina charakter funkcjonalny - forma jest wykładnikiem funkcji, do analizy i interpretacji której punktem wyjścia jest zjawisko alternacji. Jest to zalążek myślenia o języku jako o zbiorze o charakterze systemów, a nie luźnych elementów, co - jak widzieliśmy - pojawia się już w myśli Humboldta. Jest też jednostka językowa traktowana jako abstrakcyjna i relewantna forma danego układu. Podobne ujęcie odnajdziemy zarówno u Humboldta, jak i Saussure'a. Zasadnicza różnica między Baudouinem a Saussure'em zasadza się na przesłankach dowodzeniowych. Podczas gdy Saussure asubstancjalność systemu wyprowadza z morfologii, to Baudouin, wychodząc wprawdzie również od morfologii, przechodzi od razu do fonologii, gdzie opozycja substancja : forma jest szczególnie wyraźna ze względu na zestawienie języka z akustyką. De Saussure zatem sprecyzował koncepcję abstrakcyjnej struktury za pomocą systemu opozycji morfologicznych, natomiast Baudouin de Courtenay przygotował grunt dla abstrakcyjnego rozumienia języka na płaszczyźnie morfonologicznej z wykorzystaniem mechanizmu alternacji, najpierw 
morfologicznych, następnie fonologicznych, co pozwoliło mu oddzielić fizyczną substancję od językowej formy i w konsekwencji funkcji. Saussure kładł nacisk na abstrakcyjny system, Baudouin zaś - na abstrakcyjną formę (por. Heinz 1990: 19-27). Celnie zatem różnicę między obiema koncepcjami podsumowuje Edward Stankiewicz (1986: 7), którego zdaniem wspólnota celów i przyjmowanie podobnych zasad badawczych nie niwelują w wypadku obu uczonych głębokich różnic „,W sposobie stawiania i rozwiązywania językowych problemów".

Porównywane w wystąpieniu koncepcje wiąże jeden ważny rys. Humboldt, Baudouin, Saussure, będąc z krwi i kości dziećmi swoich epok, stosując zasady panujących ówcześnie naukowych analiz (Humboldt - neohumanizmu, Baudouin i de Saussure - pozytywizmu opartego na czynnikach natury biologicznej i psychologicznej, o czym świadczą m.in. używane przez nich metafory „biologiczne” i rozbudowane porównania), należeli do tych nielicznych i wybitnych przedstawicieli swych czasów niepokornego ducha, którzy dysponując tą samą wiedzą materiałową, mieli zdecydowanie szersze niż ogół horyzonty myślowe, bardziej od innych samodzielne podejście do badanej rzeczywistości, a także nieprzeciętną zdolność do naukowej syntezy. Ich neokantiańskie oblicze przejawiało się m.in. w pragnieniu uczynienia z językoznawstwa autonomicznej i na wskroś nowoczesnej gałęzi wiedzy z mentalnie pojmowanym obiektem badań starannie wydzielonym na podstawie uniwersalnych (idealnych?) przesłanek (por. Gasparov 2013: 52). Nie utożsamiali się bez reszty z panującymi w ich czasach trendami i tym samym wnosili zalążki nowego, torowali na swój sposób drogę kolejnym epokom, których treścią była, mówiąc ogólnie, reakcja przeciw istniejącemu stanowi rzeczy. Doktryny Baudouina i Saussure'a, wyrastające z reakcji przeciw skrajnościom i przerostom młodogramatyzmu, spajają dwa ważne nurty tej reakcji - ekspresjonizm w jego wersji neohumboldtiańskiej i strukturalizm czy prestrukturalizm.

Trzy omawiane tu koncepcje łączy również rys antropologiczny języka, za pomocą którego ludzie, przestawszy chodzić na czworakach, zaczęli trzymać się na dwóch nogach $z$ dumnie $i$ hardo podniesiona głową. I to właśnie stanowi o ostatecznym kształcie i naturze zarazem działalności mownej człowieka - czyni ona z nas ludzi wśród innych ludzi (por. aspekt społeczny, wyraźnie się zaznaczający we wszystkich omawianych tu nurtach). Nie istnieje język poza człowiekiem i człowiek poza językiem, nawet wówczas, gdy 
możliwości werbalizacyjne ludzi są z różnych przyczyn ograniczone. Myśleć bowiem językowo to we wszystkich porównywanych teoriach dokonywać operacji na różnicach. „Człowieczenie” (termin za Baudouinem (1904: 70)) mowy ludzkiej polega na jej uabstrakcyjnianiu, a z kolei abstrakcyjny aspekt języka dla Humboldta, Baudouina i Saussure’a stanowi o jego wartości sine qua non.

Zdaniem Friedricha Schlegla, jeśli ,gramatycy nie staną się filozofami, gramatyka nie będzie tym, czym była w czasach starożytnych, nauką pragmatyczną i częścią logiki, ani nauką w ogóle” (por. Schlegel 2018: 88). Humboldt bez wątpienia był językoznawcą i filozofem, prace Baudouina, zwłaszcza z zakresu językoznawstwa ogólnego, cechuje podejście filozoficzne, zresztą teorię języka wielokrotnie nazywa on filozofią języka, również Saussure'owi nieobce jest myślenie filozoficzno-semiotyczne. Na rys filozoficzny w twórczości Saussure’a kładzie nacisk jego uczeń, Albert Sechehaye (1917: 8), pisząc, że już w Mémoire sur le système primitif des voyelles dans les langues indo-européennes

Za problematyką historyczną jego [tj. de Saussure'a] encyklopedyczny umysł, otwarty na wszystkie ciekawostki, prawdziwie ludzki, dostrzegł problem filozoficzny, problem języka jako takiego, jego natury, jego pierwotnych przyczyn, jego życia.

Sechehaye dodaje również, że ten najbardziej ogólny zestaw zagadnień inreresował Saussure'a przez całe życie.

Wykład analizowanych tu doktryn łączy wspólna cecha. Chodzi mi o wahania, a nawet radykalne zmiany perspektywy filozoficzno-ogólnego patrzenia na opisywane zjawiska, które można odnaleźć nie tylko w różnych paragrafach czy rozdziałach ich prac, co w gruncie rzeczy zrozumiałe, lecz nawet na jednej stronie. Ktokolwiek próbował tłumaczyć Humboldta, Baudouina, Saussure'a, ten wie, jak trudno w tym zadaniu o doskonałość. Wiele zdań zdaje się niespójnych z innymi. Jest tu obecność Kanta, Fichtego, Hegla, ale nie jest łatwo ją wskazać, ponieważ wszyscy ci trzej filozofowie pisali żałośnie o języku. Najważniejszy jednak - jak się zdaje - jest wpływ Kanta [być może nieuświadomiony, choć o Humboldcie mówi się, że gdyby nawet Kant nie istniał, to Humboldt by go wymyślił (R. Haym, za: Kowalska 2001: 7-8)], spajający na najogólniejszym poziomie podejście do przedmiotu 
poznania językowego - jednostki języka ujmowanej we wszystkich analizowanych teoriach z perspektywy abstrakcyjnego pojęcia (Sprachidee u Humboldta, языка 'języka' lub aspektu cerebracyjnego u Baudouina, langue czy znaku z jego rozczłonkowaniem na signifié i signifiant u Saussure'a). Wpisane w abstrakcyjną tkankę mowy narzędzia i działania językowe stanowią warunek konieczny każdego empirycznego badania językowego i samej konstytucji języka. Tak oto idealizm kantowski położył się cieniem na quasi-realistycznych (jak np. strukturalizm genewski) metodach badania języka. To one przygotowały grunt pod paradygmaty językoznawcze bazujące na impresyjnych koncepcjach poznania. Nurty rzeczywiście realistyczne, jak na przykład nominalizm, nigdy nie stały się pożywką dla wpływowych teorii języka.

Przy wszystkich trudnościach związanych m.in. z porównywaniem terminologii Humboldta, Baudouina i Saussure'a, ich doktryny, choć w gruncie rzeczy osobne, nie stanowią wobec siebie szczelnie zamkniętych budowli, lecz tworzą pewne kontinuum. Nie sądzę jednak, żebyśmy mieli w tym wypadku do czynienia ze świadomymi filiacjami między Humboldtem a Baudouinem i Saussure'em, wpisują się one bowiem w szeroki kontekst podejścia do epistemologii dominujący w nowożytnej metanauce. $\mathrm{Z}$ teoriopoznawczego punktu widzenia proces postrzegania rzeczywistego przedmiotu badań lingwistyki we wszystkich omawianych koncepcjach ma do pewnego stopnia charakter „twórczy”. W procesie tym nasz umysł konstruuje lub rekonstruuje obiekty lingwistyczne częściowo na podstawie doświadczenia, oglądu bytów tekstowych, lecz przede wszystkim na podstawie procesów mentalno-wyobrażeniowych. Obiekty w ten sposób wytworzone (przez niektórych traktowane jako od- lub wykryte) nie są czymś w pełni rzeczywistym, ale są tylko pewnego rodzaju naszymi projekcjami. Umysł, produkując te projekcje, podlega tym samym ograniczeniom, które towarzyszą każdej jego wytwórczości, jak chociażby fatamorgana, a zatem kieruje się tymi samymi schematami, na podstawie których budowane są przez niego obiekty myślowe oderwane od wszelkiego doświadczenia. Przedstawiony mechanizm tłumaczy fakt, że o obiektach możliwych do poznania doświadczalnie potrafimy zdawać sprawę, nie czekając na dane płynące z doświadczenia. Jak widzimy, od strony epistemologicznej, koncepcje języka Humboldta, Baudouina i Saussure’a pokrywają się z hipotezą Kanta, głoszącą, że przedmioty 
doświadczenia stanowią wytwór umysłu, co trzeba uznać za jedną z postaci idealizmu (por. Ajdukiewicz 1983: 66-67).

Przywołane tu filiacje i inspiracje kantowskie są zapewne - przynajmniej w wypadku Baudouina i de Saussure'a - nieświadome oraz niezamierzone. Mogą one być efektem przemożnego i chyba uwodzicielskiego wpływu idei Kanta na całe pokolenia europejskich badaczy różnych specjalności. Bardzo możliwe też, że pomostem między Kantem a Baudouinem i Saussure'em był w jakiejś mierze Wilhelm von Humboldt (a dla Saussure'a William Dwight Whitney), lecz również mają w tym swój udział kręgi intelektualne Lipska i Berlina. W tych bowiem ośrodkach i w kontaktach z uczonymi z nimi związanych wykuwały się zręby teorii lingwistycznych Baudouina i Saussure'a.

\section{Bibliografia}

Adamska-Salaciak A., 1996, Language change in the works of Kruszewski, Baudouin de Courtenay and Rozwadowski, Poznań: MOTIVEX.

Adamska-Salaciak A., 1998, Jan Baudouin de Courtenay's contribution to linguistic theory, Historiographia Linguistica 25(121), s. 25-60.

Ajdukiewicz K., 1983, Zagadnienia i kierunki filozofii. Teoria poznania. Metafizy$k a$, Warszawa: Czytelnik.

Baudouin de Courtenay J., 1903a, Język i języki, w: A. Pietkiewicz, A. A. Kryński (red.), Wielka encyklopedya powszechna ilustrowana, t. 33, Warszawa: nakład S. Sikorskiego, s. 266-278.

Baudouin de Courtenay J., 1903b, Językoznawstwo, w: J. Aleksandrowicz (red.), Wielka encyklopedia powszechna ilustrowana, t. 33-34, Warszawa: Drukarnia Aleksandra Tadeusza Jezierskiego, s. 278-296.

Baudouin de Courtenay J., 1904, Szkice językoznawcze, t. 1, Warszawa: Z zapomogi Kasy Pomocy [...] im. J. Mianowskiego.

Baudouin de Courtenay J., 1909, Zarys historji językoznawstwa czyli lingwistyki (glottologji), w: A. Heflich, S. Michalski (red.), Dzieje myśli. Historja rozwoju nauk, t. 2(2), Warszawa: Kasa im. J. Mianowskiego, s. 86-293.

Baudouin de Courtenay J., 1922, Zarys historji języka polskiego, Warszawa: Polska Składnica Pomocy Szkolnych.

Baudouin de Courtenay J., 1975-1990, Dzieła wybrane, t. 1-6, Warszawa: Państwowe Wydawnictwo Naukowe. 
Baudouin de Courtenay J., 2002, Listy z lat 1870-1927, Kraków: Wydawnictwo Naukowe Akademii Pedagogicznej.

Baudouin de Courtenay J., 2007, Listy Jana Baudouina de Courtenay do Henryka Ułaszyna z lat 1898-1929, Kraków: Księgarnia Akademicka.

Baudouin de Courtenay J., 2011, Listy Jana Niecisława Baudouina de Courtenay, w: A. Czelakowska, M. Skarżyński (red.), Materiały do dziejów polskiego językoznawstwa. Listy Jana Niecisława Baudouina de Courtenay, Jana Łosia, Kazimierza Nitscha, Jana Michała Rozwadowskiego, Henryka Ułaszyna, Kraków: Księgarnia Akademicka, s. 29-99.

Baudouin de Courtenay J., 2016a, Autobiogram, w: M. Skarżyński (red.), Materiaty do dziejów polskiego językoznawstwa, t. 2: Jan Baudouin de Courtenay. Teksty mniej znane, Kraków: Księgarnia Akademicka, s. 23-57.

Baudouin de Courtenay J., 2016b, Materiały do dziejów polskiego językoznawstwa 2. Jan Baudouin de Courtenay. Teksty mniej znane, Kraków: Księgarnia Akademicka.

Benveniste E., 1964, Lettres de Ferdinand de Saussure à Antoine Meillet, Cahiers Ferdinand de Saussure 21, s. 93-130.

BogusŁawski A., Drzazgowska E., 2016, Język w refleksji teoretycznej. Przekroje historyczne, t. 1-2, Warszawa: Katedra Lingwistyki Formalnej UW.

Brown R. L., 1967, Wilhelm von Humboldt's Conception of Lingustic Relativity, The Hague-Paris: Mouton.

Buyssens E., 1954, Speaking and thinking from the linguistic standpoint, Acta Psychologica 10, s. 136-164.

Chomsky N., 1970, Current Issues in Linguistic Theory, The Hague-Paris: Mouton.

Collinge N. E., 1985, Laws of Indo-European, Amsterdam-Philadelphia: John Benjamins Publishing Company.

Danielewiczowa M., 2004, Przedmowa do wydania polskiego. Ferdinand de Saussure - siła paradoksu, w: F. de Saussure, Szkice z językoznawstwa ogólnego, Warszawa: Wydawnictwo Akademickie Dialog, s. 11-23.

Danielewiczowa M., 2016, Dosięgnać przedmiotu. Rzecz o Ferdynandzie de Saussurze, Warszawa: Wydawnictwa Uniwersytetu Warszawskiego.

Deme L., 1980, Egy kérdés visszafordítása. Jan Baudouin de Courtenay emlékére, halálának 50. évfordulóján, Nyelvtudományi Közlemények 82, s. 358-360.

FERron I., 2009, „Sprache ist Rede”. Ein Beitrag zur dynamischen und organizistischen Sprachauffassung Wilhelm von Humboldts, Würzburg: Königshausen \& Neumann.

Feudel G., 1976, Baudouin de Courtenay und F. de Saussure - zwei Traditionslinien in der Entwicklung der Sprachwissenschaft, STUF - Language Typology and Universals 29(1-6), s. 529-533. 
GaSParov B., 2013, Beyond pure reason. Ferdinand de Saussure's philosophy of language and its early romantic antecedents, New York: Columbia Yniversity Press.

HeInz A., 1978, Dzieje językoznawstwa w zarysie, Warszawa: Państwowe Wydawnictwo Naukowe.

HeInz A., 1990, Jan Baudouin de Courtenay jako teoretyk języka i indoeuropeista, w: J. Baudouin de Courtenay, Dzieła wybrane, t. 4, Warszawa: Państwowe Wydawnictwo Naukowe, s. 7-31.

H. Tótн I., 1997, Statika, dinamika, nyelvtörténet (Ferdinand de Saussure és Jan Baudouin de Courtenay), w: L. Büky (red.), Nyíri Antal kilencvenéves, Szeged: JATE Magyar Nyelvészeti Tanszék, s. 163-172.

Humboldt W. von, 1903-1936, Wilhelm von Humboldts gesammelte Schriften, Berlin-Leipzig: B. Behr-Friedrich Feddersen.

Humboldt W. von, 1905, Wilhelm von Humboldts gesammelte Schriften, t. 4, Berlin: B. Behr.

Humboldt W. von, 1906, Wilhelm von Humboldts gesammelte Schriften, t. 5, Berlin: B. Behr.

Humboldt W. von, 1907a, Wilhelm von Humboldts gesammelte Schriften, t. 7(1), Berlin: B. Behr.

Humboldt W. von, 1907b, Wilhelm von Humboldts gesammelte Schriften, t. 6(1), Berlin: B. Behr.

Humboldt W. von, 1908, Wilhelm von Humboldts gesammelte Schriten, t. 7(2), Berlin: B. Behr.

Humboldt W. von. (2004-2018). Wilhelm von Humboldt: Sprachwissenschaftliche Korrespondenz, [online] https://wvh-briefe.bbaw.de [03.09.2019].

Hurch B., 2018, Humboldts Gegenwart im 19. Jahrhundert, Zeitschrift für Literaturwissenschaft und Linguistik 48(4), s. 611-640.

Kant I., 2004, Krytyka władzy sądzenia, tłum. J. Gałecki i A. Landman, Warszawa: Państwowe Wydawnictwo Naukowe.

Kant I., 2013, Krytyka czystego rozumu, tłum. M. Żelazny, Toruń: Wydawnictwo Naukowe Uniwersytetu Mikołaja Kopernika.

Koerner E. F. K., 1973, Ferdinand de Saussure. Origin and development of his linguistic thought in Western studies of language (A contribution to the history and theory of linguistics), Braunschweig: F. Vieweg \& Sohn.

KowalsKa E. M., 2001, Wprowadzenie, w: W. von Humboldt, Rozmaitość języków a rozwój umysłowy ludzkości, Lublin: Redakcja Wydawnictw Katolickiego Uniwersytetu Lubelskiego, s. 5-63.

Kowalski M., 2016, Język i czas. Studium myśli naukowej Jana Baudouina de Courtenay i Ferdinanda de Saussure'a, Warszawa: Wydawnictwo Naukowe UKSW. 
LENČEK R. L., 1989, Language-Society Nexus in Baudouin's Theory of Language Evolution: Language Change in Progress, w: J. Rieger, M. Szymczak, S. Urbańczyk (red.), Jan Niecistaw Baudouin de Courtenay a lingwistyka światowa. Materiaty z konferencji międzynarodowej, Warszawa 4-7 IX 1979, Wrocław-Warszawa-Kraków-Gdańsk-Łódź: Zakład Narodowy im. Ossolińsklich - Wydawnictwo Polskiej Akademii Nauk, s. 75-81.

Lyons J., 1977, Semantics, t. 1-2, Cambridge: Cambridge University Press.

Martinet A., 1980, Éléments de linguistique générale, Paris: Armand Colin.

Meillet A., 1937, Introduction à l'étude comparative des langues indo-européennes, Paris: Hachette.

Minissi N., 1989, F. de Saussure, J. Baudouin de Courtenay and the linguistics of the time, w: J. Rieger, M. Szymczak, S. Urbańczyk (red.), Jan Niecisław Baudouin de Courtenay a lingwistyka światowa. Materiaty z konferencji międzynarodowej, Warszawa 4-7 IX 1979, Wrocław-Warszawa-Kraków-Gdańsk-Łódź: Zakład Narodowy im. Ossolińsklich - Wydawnictwo Polskiej Akademii Nauk, s. $149-156$.

Mueller H., 1966, On re-reading von Humboldt, Monograph Series on Languages and Linguistics 19, s. 97-107.

Nitsch K., 2011, Listy Kazimierza Nitscha do Henryka Ułaszyna (1905-1955), w: A. Czelakowska, M. Skarżyński (red.), Materiały do dziejów polskiego językoznawstwa. Listy Jana Niecisława Baudouina de Courtenay, Jana Łosia, Kazimierza Nitscha, Jana Michała Rozwadowskiego, Henryka Ułaszyna, Kraków: Księgarnia Akademicka, s. 2003-325.

Petit D., QuiJano C. M., 2008, Du nouveau à propos du voyage de F.de Saussure en Lituanie, Cahiers Ferdinand de Saussure 61, s. 133-157.

SAUSSURE F. DE, 1879, Mémoire sur le système primitif des voyelles dans les langues indo-européennes, Leipsick: B. G. Teubner.

Saussure F. DE, 1894a, À propos de l'accentuation lituanienne, Mémoires de la Société de Linguistique de Paris 8, s. 425-446.

SAussure F. DE, 1894b, Sur le nominatif pluriel et le génitif singulier de la déclinaison consonantique en lituanien, Indogermanische Forschungen 4(1), s. 456-470.

SAussure F. DE, 1896, Accentuation lituanienne, Indogermanische Forschungen 6(Anzeiger), s. 157-166.

SAussure F. DE, 1991, Kurs językoznawstwa ogólnego, tłum. K. Kasprzyk, Warszawa: Państwowe Wydawnictwo Naukowe.

Saussure F. DE, 1995, Cours de linguistique générale, Paris: Éditions Payot \& Rivages.

Saussure F. DE, 2002, Écrits de linguistique générale, Paris: Gallimard.

SAUSSURE F. DE, 2004, Szkice z językoznawstwa ogólnego, tłum. M. Danielewiczowa, Warszawa: Wydawnictwo Akademickie Dialog. 
SAussure F. DE, 2014, Ferdinand de Saussure: Une vie en lettres, 1866-1913, Nantes: Éditions nouvelles Cécile Defaut.

Schlegel F., 2018, „Atheneum”-Fragmente und andere frühromantische Schriften, Ditzingen: Reclam.

Schmidt J., 1865, Die Wurzel AK in Indogermanischen. Mit einem Vorworte von August Schleicher, Weimar: Hermann Böhlau.

Sechehaye A., 1917, Les problèmes de la langue à la lumière d'une théorie nouvelle, Revue Philosophique de la France et de l'Étranger 84, s. 1-30.

Sluusareva N. A., 1970, Lettres de Ferdinand de Saussure à J. Baudouin de Courtenay, Cahiers Ferdinand de Saussure 27, s. 7-17.

Sluusareva N. A., 1974, Essai de comparaison des conceptions de F. de Saussure et de W. von Humboldt, w: R. Godel, R. Amacker, T. de Mauro, L.J. Prieto (red.), Studi saussuriani, Bologna: Il Mulino, s. 265-276.

SoвоткA P., 2017, Jan Baudouin de Courtenay - językoznawca filozoficzny, gramatyk, w: Z. Zaron, Z. Greń (red.), My z nich. Spuścizna językoznawców Uniwersytetu Warszawskiego, Warszawa: Wydział Polonistyki UW, s. 7-25.

Stankiewicz E., 1986, Baudouin de Courtenay a podstawy współczesnego językoznawstwa, tłum. W. Kalaga, E. Stankiewicz, Wrocław-Warszawa-Kraków-Gdańsk-Łódź: Zakład Narodowy im. Ossolińskich - Wydawnictwo Polskiej Akademii Nauk.

Waterman J. T., 1970, Perspectives in linguistics: an account of the background of modern linguistics, Chicago-London: University of Chicago Press.

БоДУЭН ДЕ КУРТЕНЭ И., 1871, Некоторые общие замечания о языковедении и языке, Санкт Петерсбург: Печ. В.И. Головина.

БодУэн ДЕ КУРтенэ И., 1963а, Избранные труды по общему языкознанию, t. 1, Москва: Издательство Академии наук СССР.

БоДУэн ДЕ КУРТЕНЭ И., 1963b, Избранные труды по общему языкознанию, t. 2, Москва: Издательство Академии наук СССР.

Поливанов Е. Д., 1931, За марксистское языкознание. Сборник популярных лингвистических статей, Москва: Изфательство «Федерация».

СлюсаревА Н. А., 1970, Теории языковедов Казанской школы и идеи Фердинанда де Соссюра, Труды Самаркандского государственного университеma 174(1-26).

Соссюр Ф. ДЕ, 1933, Курс общей лингвистики, tłum. А. М. Сухотин, Москва: Соцэкгиз.

ШАРАДЗЕНИДЗЕ Т. С., 1980, Лингвистическая теория И. А. Бодуэна де Куртенэ и ее место в языкознании XIX-XX веков, Москва: Издательство «Наука».

ЩЕрьА Л. В., 1929, И. А. Бодуэн де Куртенэ и его значение в науке о языке (1845-1929), Русский язык в советской школе 6, s. 66. 
ЩЕрБА Л. В., 1957, И. А. Бодуэн де Куртенэ и его значение в науке о языке (1845-1929), w: Л. В. Щерба, Избранные работы по русскому языку, Москва: Государственное учебно-педагогические издательство Министерства просвещения РСФСР, s. 85-96.

\section{Wilhelm von Humboldt versus Jan Baudouin de Courtenay and Ferdinand de Saussure: \\ The philosophical sources of the modern linguistic thoughts \\ ( $\mathbf{s}$ u m m a r y)}

The article attempts to present a synthetic and confrontational outline of views on the language theory of Humboldt, Baudouin, and Saussure. The author indicates the relationship between their ideas, as well as traces the most important relations between the scholars. Finally, a hypothesis is formulated explaining the relationships between their doctrines. The conceptions of the language of Humboldt, Baudouin, and Saussure correspond to the Kant's hypothesis that the objects of experience are the product of the mind, which should be considered as one of the forms of idealism. 
